\title{
Acute liver failure secondary to hepatic compartment syndrome: case report and literature review
}

\author{
Bei Ye, M.D., Yang De Miao, M.D. \\ Department of Gastroenterology, Taizhou Municipal Hospital, Taizhou, Zhejiang, China
}

\begin{abstract}
We report a case of a patient with a delayed large intrahepatic hematoma and transient decline in hemoglobin to $62 \mathrm{~g} / \mathrm{L} 18$ days after liver injury.Abdominal computed tomography revealed seriously flattening of inferior vena cava, which was consistent with compression by the enlarging hematoma.Although traditionally there was no indication for surgical intervention, the patient developed acute liver failure with a progressive increase in liver enzymes and bilirubin. We postulated the ever-expanding hematoma might have led to dramatically elevated intrahepatic pressures that in turn restricted hepatic vein reflux and subsequently resulted in acute liver failure. Therefore, she underwent percutaneous drainage, and the decompression instantly reversed the liver injury. This phenomenon is similar to the well-described abdominal compartment syndrome, which is defined as new onset organ dysfunction or failure secondary to sustained intraabdominal hypertension and in which decompression is the standard treatment.
\end{abstract}

Key words: Computed tomograghy; liver; hepatic compartment syndrome; trauma.

\section{INTRODUCTION}

Acute liver failure due to delayed intrahepatic hemorrhage after liver injury is a rare complication but potentially life threatening. We report a case of delayed intrahepatic bleeding 18 days after liver laceration, causing compression of the inferior vena cava and hepatic veins and consequently acute liver failure. Similar with the well-defined abdominal compartment syndrome, ${ }^{[l]}$ we postulate that the expanding hematoma led to elevated intrahepatic pressure, and that in turn resulted in diminished hepatic perfusion and ischemia. To our knowledge, this "Hepatic Compartment Syndrome" is an uncommon etiology leading to acute hepatic failure in clinical practice. Hence, we also review the literature with a comprehensive overview of major clinical characteristics and current management options in order to improve the outcomes for these patients.

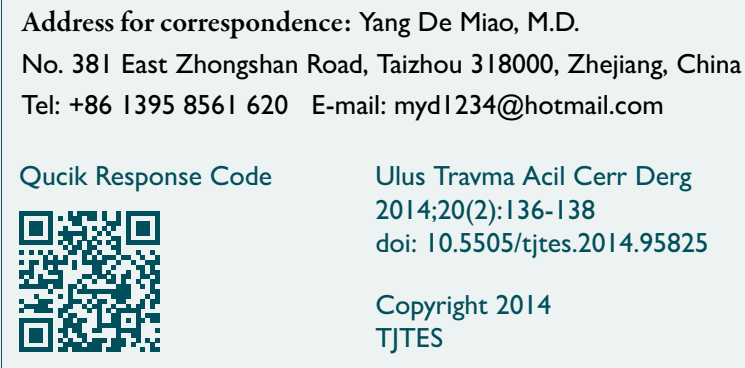

\section{CASE REPORT}

A 35-year-old woman presented to our emergency department for chest distress for 30 hours due to traffic injury. She was struck by a car on the right chest and right upper quadrant. Computed tomography (CT) demonstrated multiple right rib fractures and pleural effusion, and liver laceration with hemoperitoneum. She had no history of liver disease or ethanol abuse and was on no medication. On admission, she was alert and vital signs were as follows: blood pressure was $100 / 60 \mathrm{mmHg}$ on dopamine, heart rate was 110 beats/min, and oxygen saturation was approximate $90 \%$ on mask oxygen. On physical examination, right respiratory movement was greatly decreased and some crepitus was detected on the right side while the left lung was clear. Her abdomen was soft and there was slight right epigastric tenderness. Shifting dullness was positive and fresh blood was aspirated on abdominal paracentesis. CT scan of the abdomen revealed a grade IV laceration of the liver (Fig. I).

She underwent emergency laparotomy due to hemodynamic instability even with resuscitation. A chest tube was inserted and approximately $1500 \mathrm{ml}$ blood was drained. There was approximate $2500 \mathrm{ml}$ blood in the peritoneal cavity. Multiple lacerations were encountered in the lower pole of the spleen and splenic hilum. Severe damage in the VII segment, multiple lacerations, and subcapsular hematoma were founded in the liver. Hence, she underwent splenectomy, repair of the liver laceration and perihepatic packing with gauzes. 
Postoperatively, hemoglobin was stable and liver enzymes were greatly improved. Abdominal CT follow-up showed the liver laceration had partly recovered (Fig. I). The recovery was unevenly. However, on postoperative day 16 (18 days post injury), she developed sudden severe right upper abdominal pain and fresh blood was drained from the abdominal drainage. Laboratory findings showed a drop in hemoglobin to $62 \mathrm{~g} / \mathrm{L}$, which was remained relatively stable thereafter. Liver enzymes were again elevated and an emergency CT scan of the abdomen showed a hyperdense mass within the right lobe of the liver, measuring $16.7 \times 9.3 \mathrm{~cm}$ in diameter, traversing segments VII and VIII and bordering on segment IV (Fig I), and flattening and effacement of the inferior vena cava and right and middle hepatic veins, consistent with compression by the enlarging hematoma (Fig I). Simultaneously, the left hepatic lobe was compensatorily hypertrophic. This was consistent with restriction of hepatic reflux due the compression of liver veins and inferior vena cava by the enlarging hematoma. Over the next 24 hours, alanine aminotransferase and alkaline phosphatase elevated to $878 \mathrm{U} / \mathrm{L}$ and $858 \mathrm{U} / \mathrm{L}$ respectively, and total bilirubin increased to $203 \mathrm{umol} / \mathrm{L}$. Her mental status and overall situation worsened. We postulate that the expanding hematoma led to elevated intrahepatic pressures that in turn resulted in diminished hepatic perfusion and ischemia. This "Hepatic Compartment Syndrome" led to ischemic hepatic failure. ${ }^{[2]}$ Hence, she underwent percutaneous drainage and fortunately, the liver enzyme decreased rapidly and thereafter recovery was unevenly. Then patient was discharged on day 47.

\section{DISCUSSION}

The mortality of liver trauma is correlated with the grade of injury, varying from $8 \%$ to $56 \%$ for Grade IV injuries to $80 \%$ for Grade V. ${ }^{[3,4]}$ Complications after hepatic trauma include bile leaks, hemobilia, bile peritonitis, hemoperitoneum, hepatic necrosis, hepatic abscess, and delayed hemorrhage. The complication rate also increases with the grade of injury as those with Grade III had a complication rate of I\%, Grade IV at $21 \%$, and Grade $V$ approximate at $63 \% .^{[5]}$

For this patient, alanine aminotransferase and total bilirubin dramatically elevated on 16 days post operation, with mental status and overall situation worsening simultaneously. This acute liver failure could be explained by the congestion of hepatic reflux on CT scan because the majority of patients with ischemic hepatitis had severe underlying cardiac disease that had often led to similar passive congestion of the liver as in this case. ${ }^{[6]}$ These lead us to propose that resultant hepatic venous congestion due the compression of liver veins and inferior vena cava by the enlarging hematoma may predispose the liver to injury.

In the new guideline for management of blunt hepatic injury, a routine laparotomy is not indicated in the hemodynamically stable patient without peritonitis. ${ }^{[7]}$ Currently, nonoperative management is now the standard of care for hemodynamically stable patients with blunt hepatic trauma, with success rates ranging from $82 \%$ to $100 \% .{ }^{[8]}$ Surgery has been reserved for extensive lesions with the condition of hemodynamic instability or for the treatment of complications. ${ }^{[6]}$ A 2008 study showed that $86.3 \%$ of hepatic injuries are now managed without operative intervention. ${ }^{[9]}$ Indications for further intervention by embolization or laparotomy include hemodynamic stability that cannot be achieved after resuscitation,
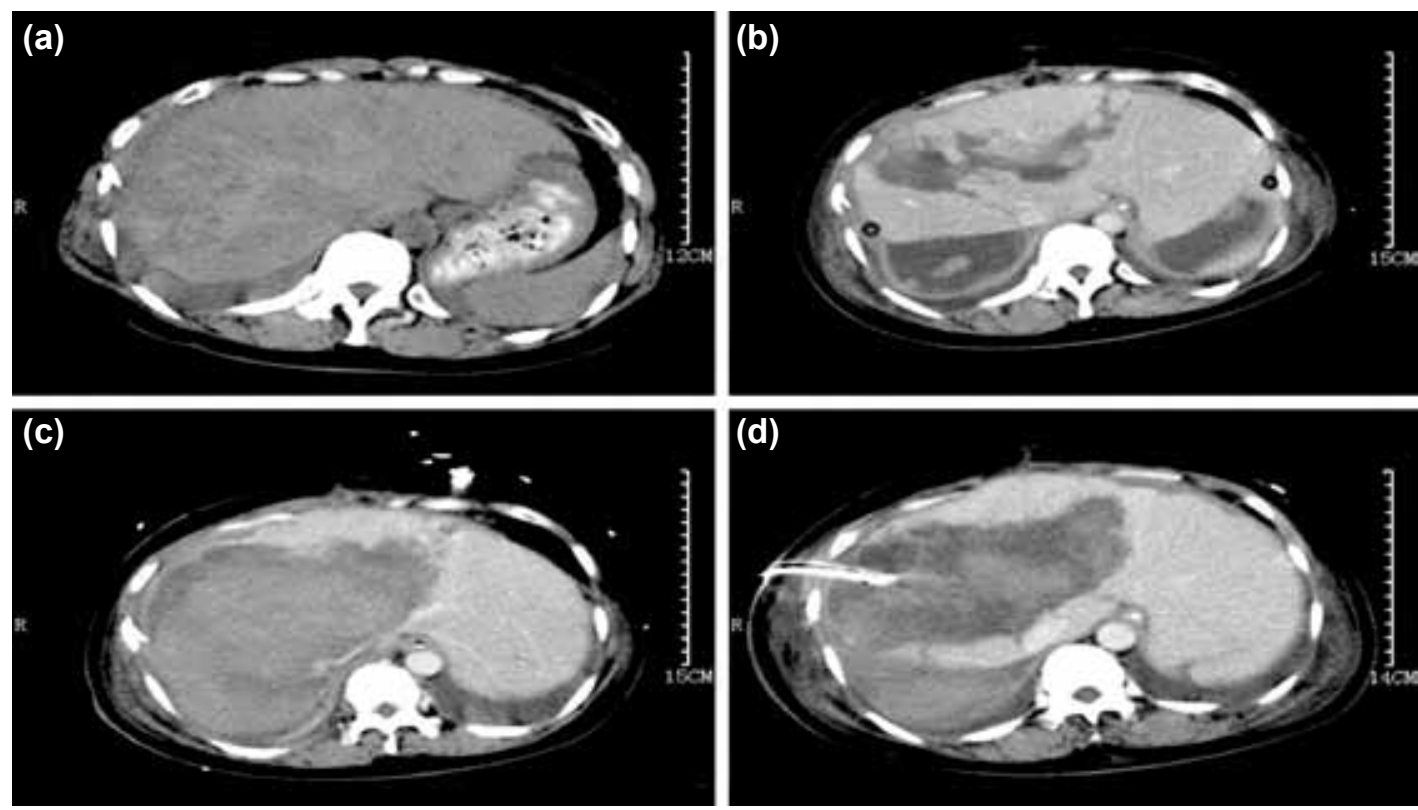

Figure 1. Evolution of the liver injury was demonstrated serially by computerized abdominal tomography. (a, b) Extensive multiloculated liver lacerations were revealed on admission and 8 days later. (c) Eighteen days later, a CT section at approximately the same level demonstrated a delayed large intrahepatic hematoma, flattening and effacement of the inferior vena cava and disappearance of the right and middle hepatic veins. (d) Nine days later after percutaneous decompression of the intrahepatic hematoma, the inferior vena cava re-opened. 
progressive fall of hemoglobin with recurrent blood transfusion, and clinical signs of peritonitis. ${ }^{[3]}$ It is worth noting that the failure of conservative treatment does not necessarily lead to an increase in the incidence of complications or mortality in centers with continued intensive therapy and the immediate possibility of performing surgery ${ }^{[6]}$ Angiography with embolization should be considered as a first-line intervention for a patient before potential operative intervention. ${ }^{[7]}$ Nearly half of the Grade III injuries and approximate all of the Grade IV injuries had active bleeding on angiography regardless of the presence of CT scan blush. ${ }^{[10]}$ However, the majority of vascular injuries are venous in liver injury; ${ }^{[6]}$ this may explain why few patients underwent angiographic embolization in some trauma centers. ${ }^{[3]}$ If hemodynamic stability could not be achieved with embolization, conversion to laparotomy was used to evacuate the hematoma and acheive hemostasis. Surgeons can refer to the algorithm for operative management of blunt liver trauma but must tailor the surgical approach to the individual injury. ${ }^{[1]}$

Our patient had a sudden delayed hemorrhage and the hemoglobin remained stable thereafter. Traditionally, there was no indication for surgical intervention. Nevertheless, the climbing intrahepatic pressure due to the enlarging hematoma caused hepatic venous congestion by compressing liver veins and inferior vena cava. Consequently, acute liver failure and worsening of the overall situation ensued. As expected, decompression by percutaneous drainage reversed the liver injury rapidly. This phenomenon is consistent with the well-described abdominal compartment syndrome in which new organ failure and vessel compromise caused by climbing intrabdominal pressure occur and decompression is the standard treatment. ${ }^{[1]}$ Similarly, it is likely that hepatic parenchymal pressure, hepatic necrosis, and hypovolemia worked in concert to cause hepatic injury in our case. ${ }^{[2]}$ Hence, we believe this syndrome could be termed as "Hepatic Compartment Syndrome".

In summary, acute liver failure in patients with rapidly expanding intrahepatic hematoma may be attributed to climbing intrahepatic pressure and hepatic necrosis. Decompression by percutaneous drainage may be an effective way to reverse the liver injury.

\section{Conflict of interest: None declared.}

\section{REFERENCES}

1. Malbrain ML, Cheatham ML, Kirkpatrick A, Sugrue M, Parr M, De Waele J, et al. Results from the International Conference of Experts on Intra-abdominal Hypertension and Abdominal Compartment Syndrome. I. Definitions. Intensive Care Med 2006;32:1722-32.

2. Nissen NN, Geller SA, Klein A, Colquhoun S, Yamini D, Tran TT, et al. Percutaneous liver biopsy after living donor liver transplantation resulting in fulminant hepatic failure: the first reported case of hepatic compartment syndrome. J Transplant 2010;2010:273578.

3. Zago TM, Tavares Pereira BM, Araujo Calderan TR, Godinho M, Nascimento B, Fraga GP. Nonoperative management for patients with grade IV blunt hepatic trauma. World J Emerg Surg 2012;7 Suppl 1:8.

4. Ordoñez CA, Parra MW, Salamea JC, Puyana JC, Millán M, Badiel M, et al. A comprehensive five-step surgical management approach to penetrating liver injuries that require complex repair. J Trauma Acute Care Surg 2013;75:207-11.

5. Kozar RA, Moore FA, Cothren CC, Moore EE, Sena M, Bulger EM, et al. Risk factors for hepatic morbidity following nonoperative management: multicenter study. Arch Surg 2006;141:451-9.

6. Seeto RK, Fenn B, Rockey DC. Ischemic hepatitis: clinical presentation and pathogenesis. Am J Med 2000;109:109-13.

7. Stassen NA, Bhullar I, Cheng JD, Crandall M, Friese R, Guillamondegui $\mathrm{O}$, et al. Nonoperative management of blunt hepatic injury: an Eastern Association for the Surgery of Trauma practice management guideline. J Trauma Acute Care Surg 2012;73(5 Suppl 4):288-93.

8. Velmahos GC, Toutouzas KG, Radin R, Chan L, Demetriades D. Nonoperative treatment of blunt injury to solid abdominal organs: a prospective study. Arch Surg 2003;138:844-51.

9. Tinkoff G, Esposito TJ, Reed J, Kilgo P, Fildes J, Pasquale M, et al. American Association for the Surgery of Trauma Organ Injury Scale I: spleen, liver, and kidney, validation based on the National Trauma Data Bank. J Am Coll Surg 2008;207:646-55.

10. Hagiwara A, Murata A, Matsuda T, Matsuda H, Shimazaki S. The efficacy and limitations of transarterial embolization for severe hepatic injury. J Trauma 2002;52:1091-6.

11. Kozar RA, Feliciano DV, Moore EE, Moore FA, Cocanour CS, West MA, et al. Western Trauma Association/critical decisions in trauma: operative management of adult blunt hepatic trauma. J Trauma 2011;71:1-5.

\section{OLGU SUNUMU - ÖZET}

\section{Hepatik kompartman sendromuna bağlı akut karaciğer yetersizliği: Olgu sunumu ve literatürün gözden geçirilmesi \\ Dr. Bei Ye, Dr. Yang De Miao}

Taizhou Belediye Hastanesi, Gastroenteroloji Kliniği, Zhejiang, China

Büyük ve gecikmiş intrahepatik hematomu olan ve karaciğer travmasından 18 gün sonra hemoglobin düzeyi geçici olarak 62 g/L’ye düşmüş bir hasta sunuldu. Karın bilgisayarlı tomografisi, genişlemiş hematomun basısılla uyumlu olarak inferior vena kavanın ciddi derecede düzleştiğini ortaya koydu. Klasik olarak herhangi bir cerrahi girişim endikasyonu olmamasına rağmen hastada karaciğer enzimleri ve bilirubin düzeylerinde giderek artan yükselme ile akut karaciğer yetersizliği gelişti. Giderek daha fazla genişleyen hematomun dramatik derecede yüksek intrahepatik basınçlara ve sonuçta hepatik vende reflüyü kısıtlayarak ardından akut karaciğer yetersizliğine yol açabilmiş olduğunu varsaydık. Bu nedenle, uygulanan perkütan drenaj ve dekompresyon karaciğer travmasını anında geri döndürdü. Bu fenomen süregelen yüksek karıniçi basınca bağlı yeni başlangıçı organ disfonksiyonu veya yetersizliği olarak tanımlanmış, abdominal kompartıman sendromuna benzemekte olup standart tedavisi dekompresyondur. Anahtar sözcükler: Bilgisayarlı tomografi; hepatik kompartıman sendromu; karaciğer; travma.

Ulus Travma Acil Cerr Derg 20।4;20(2):136-138 doi: 10.5505/tjtes.20।4.95825 